\title{
Reading Malachi's Rebukes and Promises In Historical and Corporate Context
}

\author{
PETER SHIROKOV \\ $3^{\text {rd }}$ Year, MA Theology \\ Talbot School of Theology, Biola University \\ La Mirada, California
}

\begin{abstract}
Malachi's prophetic voice continues to speak today through its interpreters. This article considers two of Malachi's oracles, namely the pronouncement against divorce (Mal 2:10-17) and a call to faithful temple tithing (Mal.3:8-12) citing some of their contemporary and popular interpretations. It notes major themes that run through the book, highlighting key cultural and historical realities of Malachi's day and its context of corporate unity. It demonstrates how differently Malachi can be understood by ignoring or utilizing the interpretive framework of historical, cultural and religious backgrounds.
\end{abstract}

\section{Introduction}

For those who listen, the prophetic writings preserved in the Bible continue to speak loudly across the ages of time. If one is to approach these ancient words as timeless divine messages, then they can translate into beliefs and theological convictions. Interpretations of divine words typically frame theology and set the stage for praxis. This paper seeks to illustrate the benefit of reading Malachi within his historical setting in order to understand the prophet's primary concerns and priorities. The relevance of Malachi's messages can be utilized for theological purposes and even inspire present day applications without disregard of its original context.

First, the readers will be introduced to some general backgrounds of Malachi. Major themes that run through the book will be surveyed, highlighting key cultural and historical realities of Malachi's day. Issues of religious devotion and motivations, as well as social and political tensions, will be considered in this process, creating an interpretive scheme. Having set 
the stage this paper will explore the interpretations of two seemingly unrelated passages in Malachi, namely the pronouncement against divorce (Mal 2:10-17) and a call to faithful temple tithing (Mal.3:8-12). The range of interpretations highlighted in this paper will illustrate how the text can be read with and without focus on historical and cultural context. Still, the overall goal of this paper is not to per se criticize instances of exegetic lacking, religious practice, or any dogma, but rather to illustrate how differently Malachi can be understood by ignoring or utilizing the interpretive framework of historical, cultural and religious backgrounds.

\section{Malachi's Background}

\section{The Messenger and Restoration Era}

The book of Malachi is full of colorful prophetic language and foresees the coming of an apocalyptic messenger. Both Jewish and Christian tradition presupposes that a person named Malachi himself wrote these oracles, but modern scholarship is uncertain of its authorship in general and is skeptical whether the book title contains the author's real name. ${ }^{1}$ The key prediction of the book states that "I, [the Lord] will send my messenger" (malachi) ${ }^{2}$ and many scholars believe that this prophetic proclamation over time became the title of the book but was not the author's proper name. ${ }^{3}$ Many questions remain unanswered. Should the prophet himself

\footnotetext{
${ }^{1}$ Several commentators note that the LXX uses the name Malachi for the heading of the book but in 1:1 clearly translates it as "by the hand of his angel/messenger" (en cheiri angelou autou), making it not a personal name by attaching a second person possessive ending instead of the first person as it appears in the Masoretic Hebrew texts. See Brevard S. Childs, Introduction to the Old Testament as Scripture, (Philadelphia: Fortress Press, 1982), 489; S. R. Driver, An Introduction to The Old Testament Literature, (Cleveland: The Word Publishing, 1963), 356 Pieter A. Verhoef, The Books of Haggai and Malachi, (Grand Rapids: Eerdmans, 1986), 154. Joyce G. Baldwin, Haggai, Zechariah, Malachi: An Introduction and Commentary, (Downers Grove: Inver-Varsity Press, 1972), 212; Walter Bruggemann, An Introduction to the Old Testament: The Canon and Christian Tradition, (Louisville: Westminster John Knox, 2003),489, 492. The title of the book Malachi means "my angel" or "my messenger" in Hebrew and the issue is the suspicion that this is not a real name. The Jewish tradition is substantiated by Targum Yonatan which portrays malachi not as a name but rather as a title and identifies the prophet himself as Ezra, the scribe. See Verhoef, 154; Bruggemann, 489. Megilah 15a preserves a similar opinion, but other Talmudic texts such as Sotah $48 \mathrm{~b}$ and Rosh Hashanah 19b suggest that Malachi was a proper name.

${ }^{2}$ Mal. 3:1, All Scriptural quotations are from the NASB, unless otherwise noted.

${ }^{3}$ George Arthur Buttrick, gen. ed, The Interpreter's Bible, Vol. VI, (New York: Abingdon, 1956), 1117; Otto Eissfeldt, Peter R. Ackroyd, trans., The Old Testament: An Introduction, (New York: Harper and Row Publishers,
} 
be presumed to be this messenger? Is the messenger a divine figure, described as "the Lord" in Mal 3:1? ${ }^{4}$ Peterson suggests that it was typical to understand prophets themselves as messengers of the covenant, ${ }^{5}$ but perhaps the ambiguity in this proclamation is deliberate. It is clear, however, that Malachi uses the image of the messenger specifically in connection with the covenant. The covenant is central to the message which is to be delivered and this apocalyptic messenger is directly connected to the restoration and to judgment of those who neglect the stipulations of God's covenant with Israel (Mal. 3:3-6).

While the authorship of these oracles and the messenger of Malachi remain a mystery, there is much more scholarly consensus on the approximate dating of Malachi. A very popular opinion among scholars is that Malachi's writings belong to the period between HaggaiZachariah (c. 520) and Nehemiah-Ezra (c. 400). Since the topic of temple worship is addressed explicitly by the writer of the oracles, many believe it indicates that it was already restored ${ }^{6}$ Not only was Temple worship apparently restored in Malachi's time ${ }^{7}$ but also, as seen by the title "governor" (1:8), the land was still under Persian rule. The restoration of the spiritual worship center does not coincide with political independence and perhaps, in Malachi's day, restoration was not seen as genuine or divinely initiated by the returned exiles. A likely reconstruction suggests that Ezra returned to Jerusalem with the second group of exiles during Xerxes and Artaxerxes I. Nehemiah came with the third delegation from Persia and he rebuilt the walls of

1965), 441; Paul Nadim Tarazi, The Old Testament: An Introduction, Vol. 2, (Crestwood, NY: St. Vladimir's Seminary Press, 1994), 204; Bruggemann, 258; Baldwin,, 357; Driver, 211.

${ }^{4}$ In Hebrew this general title "Lord" (Adon) can have a number of possible meanings. See Walter C. Kaiser, Messiah in the Old Testament, (Grand Rapids: Zondervan, 1995), 288.

${ }^{5}$ David L. Peterson, Zechariah 9-14 and Malachi: A Commentary, (Louisville: Westminster John Knox Press, 1995), 210.

${ }^{6}$ Eugene H. Merrill, An Exegetical Commentary: Haggai, Zechariah, Malachi, (Chicago: Moody Press, 1994), 378; Eissfeldt, 442; Kaiser, 15; Baldwin, 213; Charles L. Feinberg, The Minor Prophets (Chicago: Moody Press, 1976), , 249; Childs, 489.

${ }^{7}$ It appears from the prophet's criticism of temple practices (Mal 1:7-10, 12, 14; 3:8) that the prophet lived when the temple system already functioned. 
Jerusalem. Nehemiah then returned to Persia and some scholars believe that Malachi prophesied during the period of the governor's absence. ${ }^{8}$ It is likely that Nehemiah instituted his reforms after he returned from Persia with the fourth group of Israelites. Some suppose that Malachi prophesied at this point in history, because his messages address similar problems mentioned in the writings ascribed to Ezra and Nehemiah. ${ }^{9}$

Andrew Hill believes that Malachi most likely "addressed a recently formed province in the Persian satrapy of Eber Nahara during the reign of Darius I." ${ }^{10}$ Recapping the historical events of Darius's visit to Egypt, he wonders whether the messenger who is supposed to prepare the way is an allusion to the Persian king himself. ${ }^{11}$ It is logical that Darius would have passed through Israel on his way to Egypt. It is generally assumed that Cyrus and his successors were favorably disposed to the Israelite religion, since he initiated the rebuilding of the Jerusalem temple, but Hill explains that "the Persian royal policy was not so much a demonstration of cultural sensitivity and religious tolerance, as it was the expediency of political pragmatism... Such policy was designed to secure loyalty and establish stability in the Persian satrapies." ${ }^{12}$ Hill states that according to the Behistun inscription, just a year after sanctioning the Jerusalem temple, Darius I, in order to gain control and loyalty, promoted the worship of Apis in Egypt. He later commissioned the construction of temples for Amon at Hibbs and Horus at Edfu. ${ }^{13}$ In a broader sense, Hill is correct; anyone who proclaims and calls people to faithfulness of the covenant can be called the messenger of the covenant. This politically-

\footnotetext{
${ }^{8}$ Robert L. Alden, "Malachi” in The Expositor's Bible Commentary: Daniel-Malachi, Vol. 7, gen. ed. Frank E. Gaebelein, (Grand Rapids: Zondervan, 1984), 701.

${ }_{9}^{9}$ Andrew E. Hill, The Anchor Bible: A New Translation with Commentary: Malachi, (New York: Doubleday Dell Publishing, 1998), 51; Verhoef, 156- 157; Driver, 357; Norman L. Geisler, A Popular Survey of the Old Testament, (Grand Rapids: Baker Book House, 1987),297.

${ }^{10}$ Hill, 74.

${ }^{11}$ Ibid, 55 .

${ }^{12}$ Ibid, 66.

${ }^{13}$ Ibid, 54.
} 
motivated restoration of Israel can be seen as a reasonable explanation of the religious apathy in the time of Malachi. If sanctioning the construction of the Jerusalem temple was seen as only political expediency, it is no wonder that sincerity in worship was absent among the priests and worshipers. $^{14}$

\section{The Shattered Expectations}

Noting the feeble state of the returned remnant, the dependence on Persian authorities helps one to grasp Malachi's general tone and the issues the prophet addresses in his speeches. Looking at the succession of biblical prophets, after Ezekiel's promise of a glorious kingdom, after the rebuilding of the temple, the task of Malachi, according to Smith, was to "rekindle the fires of faith in the hearts of a discouraged people... The hopes centered in Zerubbabel were dissipated and shattered. The glowing pictures of Haggai and Zechariah were not realized. The first zeal for the new temple rapidly cooled." 15 Thus, examining this historical setting even briefly, it is possible to see how shortly after the completion of the temple gloomier times set in perhaps because the promises of Zechariah and Haggai did not immediately come true. The political realities of the day did not correlate to the anticipated restoration and thus temple worship and morale in general suffered. Perhaps the lack of retribution for the obvious impiety of community leaders and general lack of justice led to feelings of cynicism and the very idea of a just God was questioned in people's minds. The leaders, the priests, did not serve as examples and were themselves discouraged. ${ }^{16}$ Corporate unity was desperately needed, but the attitude of disbelief affected how the returned exiles saw their covenantal responsibilities. It was the task of

\footnotetext{
${ }^{14}$ Ezra records that King Cyrus permitted Jewish captives to return to their homeland and encouraged them to reestablish their temple in Jerusalem. The first group returned to Jerusalem and construction began shortly after, but the construction of the temple was interrupted with setbacks. First Cambyses was a co-regent with Cyrus and later Darius I ascended to the throne of Persian Empire and based on the biblical record the Jerusalem Temple was finally completed during his reign.

${ }^{15}$ John Merlin Powis Smith, ICC: The Exegetical Critical Commentary on the Book of Malachi, (Skokie, IL: Vrada Books, 2005), 11.

${ }^{16}$ Buttrick, 1118; Driver, 357.
} 
the prophet to exhort them to fidelity.

\section{The Corporate Theme}

The overarching theme of corporate covenantal faithfulness is seen in virtually all the exhortations of this book. It runs as a common thread through the first chapter as God's love for Israel (1:2-4) and is seen opposite Israel's corporate failed response in defiling sacrifices (1:614). In the second chapter the prophet reminds the priests of the "covenant of Levi" (2:1-9), then compares the covenantal faithfulness of the Israelites to God with their divorce practices (2:1016). In the end of the second chapter the prophet begins speaking about justice (2:17), which segues into the announcement of the "messenger of the covenant" in the third chapter (3:1-5) and is followed by the rebuke over covenantal tithes obligations (3:6-12) after which the prophet reassures his listeners about justice and exalts the wisdom of serving God faithfully (3:13-17). In chapter four the theme of the covenant is revisited again with images of Horeb and remembrance of Moses (4:4) as the prophet assures his audience of a future judgment in the final verses of the book.

The crucial importance of cultural and historical backgrounds cannot be underestimated or set aside in interpreting the meaning of Malachi's oracles. Looking at Malachi's oracles without the recognition of the corporate covenantal faithfulness themes can lead to misinterpretation of the prophet's overall message. Omitting the insights of the particular historical, political and religious tensions of Malachi's time, losing sight of the restoration events and the audience's expectations also severely limits one's ability to grasp the intended impact of the prophet's message. 


\section{Interpretations of Malachi's Pronouncements}

\section{Rebuke of Divorce}

If Malachi's pronouncements are to be interpreted in light of the above mentioned historical realities then what would his rebuke about divorces sound like in this particular context? What was the desired effect of his words? How might such a background affect the implied meaning of his message?

Do we not all have one father? Has not one God created us? Why do we deal treacherously each against his brother so as to profane the covenant of our fathers? Judah has dealt treacherously, and an abomination has been committed in Israel and in Jerusalem; for Judah has profaned the sanctuary of the LORD which He loves and has married the daughter of a foreign god. As for the man who does this, may the LORD cut off from the tents of Jacob everyone who awakes and answers, or who presents an offering to the LORD of hosts (Mal. 2:10-12).

As one reads, the corporate language and the context of national restoration in Malachi set forth ideas of national unity. If the nation is to be restored, then the division that characterized the Northern and Southern kingdoms must be reversed and the prophet's inclusive language seems to reflect this notion. Judah is being treacherous and Israel is involved in abominable acts. Anyone from the "tents of Jacob," from any tribe, may be cut off for such behavior. It seems that the condemning language is deliberately universal. This prophetic chastisement of the Israelites that addresses divorces and unions is thus directly tied to the broader topic of national unity.

This is another thing you do: you cover the altar of the LORD with tears, with weeping and with groaning, because He no longer regards the offering or accepts it with favor from your hand. Yet you say, 'For what reason?' Because the LORD has been a witness between you and the wife of your youth, against whom you have dealt treacherously, though she is your companion and your wife by covenant. But not one has done so who has a remnant of the Spirit and what did that one do while he was seeking a godly offspring? Take heed then to your spirit, and let no one deal treacherously against the wife of your youth" (Mal. 2:13-15). 
Even the very surface reading of this section reveals that Malachi's message to Israel is full of pictorial family language. The theme of marital fidelity is common prophetic imagery (Ezek. 16:8; Hos. 2:19-20; Is. 54:2; Jer. 2:2, 3:14), but Malachi approaches the family relationship in a unique way, specifically highlighting the communal covenant and issuing harsh judgment on divorces. The verses speak of actual unfaithfulness to spouses and spiritual unfaithfulness to God in one breath and the imagery mingles as if on purpose. The inhabitants of Judah married "the daughter of a foreign god." It seems that God says to Israel, through the prophet, that his people treat God in the way they treat their wives. They break unions with them and marry another when it is expedient. The infidelity in their marriages is a reflection of values that carry over into their covenantal relationship with their God.

"For I hate divorce," says the LORD, the God of Israel, "and him who covers his garment with wrong," says the LORD of hosts. "So take heed to your spirit, that you do not deal treacherously." You have wearied the LORD with your words yet you say, "How have we wearied Him?" In that you say, "Everyone who does evil is good in the sight of the LORD, and He delights in them," or, "Where is the God of justice?" (Mal. 2:16-17).

Malachi 2:10-17 speaks emphatically about God's hatred of divorce. It is a strong prophetic condemnation. Unfortunately the core message of this passage is often presented entirely outside of the historical context and setting of Malachi. What exactly is the disdain for divorce in Malachi's prophecy? From the context it is evident that the prophet exposes the sins of the entire nation, Israel and Judah. In Malachi 2:10 he says, “...for Judah has profaned the sanctuary of the LORD which He loves and has married the daughter of a foreign god." The first impression is that the prophet is simply talking about idolatry, about spiritual unfaithfulness. Just as Israelites are sons of their God, so the pagan women were daughters of their idols and herein lies the transgression. But is it equally possible that the actual practice of intermarriage was a problem in the mind of the prophet as well? John Collins notes that there is a division among 
scholars as to the exact nature of the transgression of Israel: infidelity to God or intermarriage with foreigners. ${ }^{17}$ The language truly mingles the ideas and both messages can be true. They are not mutually exclusive.

In 2:13 Malachi addresses another sin, yet continues the topic of marriage. Malachi 2:14 says: “...Because the LORD has been a witness between you and the wife of your youth, against whom you have dealt treacherously, though she is your companion and your wife by covenant." The prophet says that Israelites not only "married the daughter of a foreign god" (v.11), they have "dealt treacherously" (v.11) with "the wife of their youth" who is a "companion and your wife by covenant" (v.14). How did the Israelites deal treacherously with their wives? Malachi also adds that this treachery jeopardized the "godly offspring" (v.15). Is the prophet talking about divorce or some other mistreatment? Commenting on verse 14, John Smith writes: "The only natural interpretation of this is that the men of Judah in large numbers have in mature life divorced the wives whom they had married in the heyday of their youth. The occasion of these divorces, as appears from 2:11, was the desire to marry foreign women."18

Verses 15 and 16 form a single thought. Verse 16 begins with causative "for/because" (ki) and should be read as a continuation of a thought: “...let no one deal treacherously against the wife of your youth 'for I hate divorce,' says the LORD, the God of Israel...” (Mal. 2:15-16). The prophet insists that God is genuinely upset with the divorces of Israelites from the "wives of their youth". The prophet describes the sin itself with the verb "deal treacherously" (bagad) in verses 15 and 16. In verse 11 Judah's marriage to the "daughter of a foreign god" is described with the same verb. Which treachery is discussed in verses 15-16? Based on Malachi's language

\footnotetext{
${ }^{17}$ John J. Collins, "Marriage, Divorce and Family in Second Temple Judaism” in Leo G. Perdue, Joseph Blenkinsopp, John J. Collins, Carol Myers, Families in Ancient Israel, (Louisville: Westminster John Knox Press, 1997), 123.

${ }^{18}$ Smith, 52.
} 
it is possible that not only is divorce in view here, but remarriage also, and most probably remarriage to the "daughter of a foreign god" (v.11). Peter Craigie writes, “...the reason for divorce, namely remarriage to a person of a different religion symbolized not only a decline in the religious faith of those men getting divorced, but it was also the 'kiss of death' for the future of Israel's religion."19 Such unions will certainly not produce "godly offspring" (v.15).

Some commentators do not see the remarriage issue in Malachi 2:10-17 as central, concentrating mainly on the issue of divorce itself (v.16). ${ }^{20}$ Yet other scholars point out the desire and remarriage to foreign women as the treacherous aspect of divorce that particularly angers God according to Malachi. ${ }^{21}$ After all, divorce was allowed in Deuteronomy 24:1. It was not desirable, but permissible in God's covenant law. Nehemiah experienced similar issues of intermarriages as Malachi did, and ironically, his solution was divorce. Why does Malachi express such strong and absolute condemnation of a previously permitted and even legislated practice? Perhaps because of some particular treachery and abuse, which occurred in his day. The provisions of any law can be abused and twisted and that would alter and pervert the very purpose of the original legislation.

\section{Reading Malachi through the New Testament Prism}

The modern interpretations of Malachi's pronouncement on divorce are often influenced by the New Testament teachings on this very issue. New Testament readers are well aware of Jesus' teachings about divorce (Luke 16:18; Mark 10:2-12; Mat 5:31-32, 19:3-9) stating that

\footnotetext{
${ }^{19}$ Peter C. Craigie, Twelve Prophets, Vol. II, (Louisville: Westminster John Knox Press, 1885), 237.

${ }^{20}$ Peterson, 205; Collins, 125-127; Alden, 117-118; John F. Walvoord, Roy B. Zuck, The Bible Knowledge Commentary, (Colorado Springs: Cook Communications, 2000), 1582.

${ }^{21}$ Raymond B. Dillard, Tremper Longman III, An Introduction to the Old Testament, (Grand Rapids: Zonvervan,1994), 441; Gershon Brin, "Divorce and Qumran" in Legal Text and Legal Issues, M. Bernstein, F. Garcia Martinez, J. Kempen eds., (Leiden: Netherlands: Brill Publishing, 1997), 236; Ken M. Campbell, Marriage and Family in the Biblical World, (Downers Grove: Inver-Varsity Press, 2003), 51-52; Karl William Weyde, Prophecy and Teaching, (New York: De Gruyter, 2000), 275, Hennie J. Marsman, Women in Ugarit and Israel: Their Social and Religious Position in the Context of Ancient Near East, (Leiden: Netherlands: Brill Publishing, 2003), 187.
} 
divorce is absolutely unacceptable. Jesus is interpreted to teach that divorce is legitimate only in the case of adultery, but even then remarriage is out of the question and equal to adultery. This teaching of Jesus produces a strong tension with the text of Deuteronomy 24:1-4. Jesus seems to forbid divorce, citing only one exception to his rule, but Torah clearly allows it and does not qualify it so rigidly. To alleviate the tension, Malachi's strong words on divorce in 2:16 are often used alongside Jesus' teaching, as an Old Testament proof text against the practice of divorce. Malachi's rhetoric "for I hate divorce" (2:16) communicates God's strong displeasure with the practice. Yet too often the prophet's words are not allowed to speak in their own context and are simply attached to an entirely different setting by simply aligning Jesus' words with Malachi's rebuke without adequate explanation. ${ }^{22}$

Those who study the disputes of Hillel and Shammai concerning divorce as preserved in the Mishna (Gittin 79b, Gittin 90a, Kiddishin 65a-b), notice that the primary issue for them and most Jews of Jesus' day was not the possibility of divorce but its legality or, to be even more precise, the proper causes and motivation for such action. The divorce could be considered wrongful and even invalid if the cause was not weighty or if it was superficial according to Shammai. Hillel on the other hand believed that a legal divorce could occur for most superficial reasons. A generation before Jesus, Shammai singled out spousal infidelity as the only valid reason for divorce. This would mean that if remarriage was to take place after an improper or illegal divorce, then both people in the new marriage would technically be committing adultery. The reason and the motivation for divorce was very much a point of discussion between the religious leaders of that period of history. Shammai also condemned any divorce accompanied by desire and intent to instantly marry someone more desirable, when Hillel would have

\footnotetext{
${ }^{22}$ R. Kent Hughes, The Sermon on the Mount: The Message of the Kingdom (Wheaton: Crossway Books, 2001), 115-116; Thomas Walter Manson, The Teaching of Jesus: Studies of its Form and Content (New York: Cambridge University Press, 1955), 293.
} 
permitted that. Jesus' teachings were not in a vacuum and this very topic has been debated even in his day by the disciples of Hillel and Shammai. Looking at Jesus' teachings in light of this rabbinic subtext allows one to see that his pronouncement carries a nuance that the gospel narratives themselves are not mentioning explicitly, a nuance that would be certainly known to those who posed the questions to him about the laws of divorce. This nuance can provide a foundation for historically accurate interpretations of this teaching. It offers a possibility that Jesus condemned divorce not in an absolute fashion, but in cases when men had an ulterior motive for instant remarriage, and therefore abused their right to send away their wives for a legitimate reason.

It is not unusual to encounter Malachi's powerful denunciation of divorce in isolation of historical setting and the larger pericope. Steven Post contrasts Malachi and Jesus opposite the Deuteronomy divorce passage. He writes, "Malachi (and later Jesus) present a sharp contrast to the position of Deut. 24:1-4 which allowed a man to have a certificate of divorce for even most trivial reasons... Malachi seems to anticipate the prophetic position taken by Jesus in Mark 10:2$12 "$ - he writes. ${ }^{23}$ In this instance Malachi's divorce pronouncements are utilized to directly support Jesus' teaching. Too often this famous passage is used as a proof text without explanations about historical meanings and corporate nature of Malachi's words. ${ }^{24}$ There are writers who are conscious of the original context of Malachi. Darrel Bock, for example, commenting on Jesus' divorce teaching, reminds his readers that "this saying in Luke is not designed to be a detailed presentation of Jesus' views on divorce, it merely sets out the most

\footnotetext{
${ }^{23}$ Steven G. Post, "Family" in Encyclopedia of Christianity, Erwin Fahlbusch ed., Geoffrey William Bromiley trans. (Grand Rapids: Eerdmans, 2001), 284.

${ }^{24}$ Tom Hale and Stephen Thorson, Applied New Testament Commentary: Applying God's Word to Your Life (Colorado Springs: David C Cook Publications, 2007), 89. Amy Jill-Levine, "The Word Becomes Flesh: Jesus, Gender and Sexuality" in Historical Jesus in Recent Research Vol. 10, James D. G Dunn and Scot McKnight, eds., (Winona Lake: Eisenbrauns, 2005), 516; Walter C. Kaiser Jr., Peter H. Davis, F.F. Bruce, Manfred T. Brauch eds., Hard Sayings of the Bible, (Downers Grove: Inver-Varsity Press, 1996), 176.
} 
basic standard as an illustration of the moral tone Jesus desires." ${ }^{25}$ Malachi's oracles have much to contribute to the greater theological discussion on divorce. Danzil Chatty explains, "The book of Malachi sets the tone for this era in the area of marriage strategy with its insistence that God desires a 'godly offspring.' In the circumstances addressed by Malachi, what God hates is the divorce of Jew and Jew; there is a silence about the divorce of Jew and non-Jew." ${ }^{26}$ Chatty further explains Ezra's marriage reforms and defensive strategy by which females born in the covenant are allowed to stay, and as described in Ezra 9-10 and Nehemiah 13:23-31 unions with foreign women are undesirable. Is Malachi's message and Jesus' words about divorce in the gospels the same? Is he addressing the same scenario or similar concerns? All this does not discredit Jesus' teaching on divorce, because he is answering a particular loaded question of his contemporaries and his words stand by themselves. Malachi's words likewise speak to his audience and to an entirely different circumstance of not individual, but corporate unfaithfulness and low regard for covenant relationships.

It is hard to imagine that Malachi's pronouncement did not play any role in the first century discussions on the legality of divorces. But it is not likely that his words settled the issue itself. John Goldingay explains, "He (Malachi) is concerned with Judean men to keep faith with their Judean wives in the context of their covenant relationship with them and with Yhwh."27 Based on historical and grammatical background, Malachi's passage basically says that God hates treacherous divorces, divorces for the sake of marrying foreign wives, which would be useful for alliances, but they betray the faithful partner and more so the covenant with God. The treachery in Malachi's view may also be greater than the sins of individuals, since the passage

\footnotetext{
${ }^{25}$ Darrel L. Bock, Luke, (Downers Grove: Inter-Varsity Press, 1994), 270.

${ }^{26}$ Danzil Chatty, Divorce Discourses: A Biblical Dilemma (New Delhi: India: Concept Publishing, 2007$), 95$.

${ }^{27}$ John Goldingay, Old Testament Theology: Israel's Life, (Downers Grove: Inter-Varsity Press, 2009), 378.
} 
speaks to corporate practices. ${ }^{28}$ The prophet may be referring to Israel's unfaithfulness, the willingness to divorce their God, to trade him for another and then produce an ungodly offspring, later wondering why there is no blessing. Walter Kaiser and F. F. Bruce believe that both aspects are at hand: the "spiritual harlotry" and the very physical "mixed marriages." 29 The marriage and God's covenant relationship with Israel is often the topic of prophetic messages and it is possible that these words were intended to speak on more than one level. Having looked at the cultural and historical backdrop of the book, at political, social and spiritual turmoil, at the particular situation of the remnant the survival strategy becomes apparent to the reader. In Malachi God despises when Jews abandon their Jewish wives to marry foreign women. The prophet speaks harshly to such practices because they undermine the intended restoration and doom Israel to repeat their history. It seems that Malachi's words about divorce carry a particular nuance and are not as straight forward as they sometimes can be presented to be.

\section{Rebuke and Promise of Tithes}

Norman Geisler believes that the message of Malachi is directed towards "the remnant a few generations after the Temple was rebuilt. The temple was rebuilt, but they had lost the spiritual fervor of their forefathers and both priests and people had backslidden. It was a day of moral and social decline." ${ }^{30}$ It is natural to expect that the prophet would call people to uphold various aspects of the Sinai covenant because this is a normal function of the prophet. If the temple was truly functioning in Malachi's day as the first chapter seems to indicate (Mal. 1:710), then the rebuke about tithes is fitting and appropriate. Tithes and support of the temple system is one clear obligation of the Sinai covenant (Lev. 27:31-34, Num. 18:26, Deut. 12:6; 26:12).

\footnotetext{
${ }^{28}$ Alden, 716.

${ }^{29}$ Kaiser, Hard Sayings, 349.

${ }^{30}$ Norman L. Geisler, 297.
} 
Will a man rob God? Yet you are robbing Me! But you say, 'How have we robbed You?' In tithes and offerings. You are cursed with a curse, for you are robbing $\mathrm{Me}$, the whole nation of you! Bring the whole tithe into the storehouse, so that there may be food in My house, and test Me now in this," says the LORD of hosts, "if I will not open for you the windows of heaven and pour out for you a blessing until it overflows. Then I will rebuke the devourer for you, so that it will not destroy the fruits of the ground; nor will your vine in the field cast its grapes," says the LORD of hosts. All the nations will call you blessed, for you shall be a delightful land," says the LORD of hosts (Mal. 3:8-12).

Malachi accuses Israel of robbing God by not bringing the entire tithe to the temple. The tithes were to be brought to the "temple storehouse" (beit haotzer), so that the priests would have food provided for them. The prophet explains that God did not need tithes for himself, but this was an obligation of the nation towards the priests. The priests were demoralized and insincere and depressed, possibly because the people did not want to support them and were expressing this by not tithing. It should be clear that Malachi voices a call to covenant fidelity, not a plea for funds. Ancient historians such as Josephus ${ }^{31}$ and modern ones such as Amélie Kuhrt are of the opinion that the newly rebuilt Jerusalem temple and its administration must have been sponsored by the Persian government for quite some time, although it is hard to determine exactly how this sponsorship worked. ${ }^{32}$ The temple funding program could have been a 'tax rebate' or a grant. ${ }^{33}$ In either case this makes Malachi's call to bring in all the tithes into God's house (Mal. 3:8-12) also a very practical appeal that becomes a reality in Nehemiah's day. ${ }^{34}$ By robbing God, the people were under a "curse" (mearah) in v. 9, which concerned their fields and crops and could be reversed (v. 11). ${ }^{35}$ By not bringing to the temple the tenth of their produce they actually not only deprived the priests of food, but they also deprived themselves of the covenantal blessings.

\footnotetext{
${ }^{31}$ Antiquities 11.75-119.

${ }^{32}$ Mordechai Cogan, “Achaemenid Inscriptions: Cyrus Cylinder” in Context of Scripture, William W. Hallo and K. Lawson Younger, (Leiden; Boston: Brill, 2000), 314.

${ }^{33}$ Hill, 66.

${ }^{34}$ Verhoef, 159.

35 Verhoef, 305.
} 
The covenantal language reminiscent of Deuteronomy is easily noticeable in verses $10-12$. In Malachi's day the tithes were understood as provisions of the covenant directly tied to the land of Canaan in which they lived as tenants (Lev.20:22; 25:23). The covenant spelled out the blessings and the curses that were connected to the land and this language was highly relevant to the newly returned exiles, who themselves experienced the curse of expulsion only a generation ago.

\section{Reading Malachi Through A Fundraising Prism}

To many modern readers of the prophets, the meaning of Malachi's words on tithing may be inseparable from the fundraising context in which it is often utilized. It is impossible to document countless pulpit sermons and television pitches of cause and effect prosperity but a few typical examples of such interpretations can be found in print. David Yong-Gi Cho writes that the "secret of prosperity - tithing" and if one gives to God he will give back more bountifully. He continues, "giving one tenth of your income, carries promises of blessing and prosperity... If you do not follow God's pattern in tithing, your tithing will not be recognized. You will be unable to receive the full blessing of prosperity that God desires to give you." ${ }^{36}$ In her writings on tithes Annice Booth also quotes from Malachi and writes, "in the act of tithing we set in motion a cause/effect sequence - giving creates a vacuum which the universe rushes to fill with abundance. For nature abhors a vacuum." She describes the tithe as "a leap of faith in your bargain with God". ${ }^{37}$ Meade Malone explains, "our tithing is an act of worship and reverence to God is the key that unlocks the door to financial blessing prepared for each of us before the foundation of the word." ${ }^{38}$ Peter Wade offers another perspective on Malachi's promises of blessing, "anything God did for Old Testament people, He does greater and better

\footnotetext{
${ }^{36}$ David Yong-Gi Cho, Solving Life's Problems (Alachua: FL: Logos Bridge Foundation, 1980), 37-38.

${ }^{37}$ Annice Booth, Secrets of Prosperity: Abundance in the $21^{\text {st }}$ Century (Gardiner: MT: Summit University Press, 2000), 146-150.

${ }^{38}$ Meade W. Malone, The Plan: Unlocking God's Financial Blessing for Your Life (Bloomington: Author House, 2010), 28.
} 
for New Testament believers... He is not going to give me anything less than that." ${ }^{39}$ It is not uncommon to encounter an opinion that Christians are responsible to tithe and that modern church is no different from the temple storehouse. ${ }^{40}$ The challenge "to test God" through tithing in order to receive a blessing or avoid a curse is another frequently used punch line. ${ }^{41}$

On the other hand, Kendall, Alcorn and many other writers accurately note that financial obligations were quite different for Israel, because they had three tithes, one for the priests, described in Num. 18:21,24, another for festivals in Deut. 12:17-18, 14:23 and a third for the poor in Deut 14:28-29; 26:12-13 ${ }^{42}$ In his book on giving, Alcorn attempts to relate Mal. 3:8-12 to church giving, but later joins others in admitting that the above mentioned covenantal passages do not guide modern Christian giving. ${ }^{43}$ There seems to be a slight tension with enthusiastic implementation of some of the pronouncements from the Old Testament and dismissal of other directions.

While the popular gospel narratives about the widow's mite (Mark 12:38-44; Luke 21:14), paying taxes to Caesar, and giving to God (Mark 12:17; Luke 20:25; Matt. 22:21), among others, are seen as examples of personal financial responsibility, Malachi's message on tithing is radically different. It concerns the covenant and specifically addresses the corporate context. God promises blessings and prosperity not to individuals, but to a nation. The entire passage on

\footnotetext{
${ }^{39}$ Peter Wade, Seeds and Secrets: Cultivating God's Seeds and Applying His Secrets to Become Victors, Not Victims (Seaford, AU: Positive Word Ministries, 2008), 117.

${ }^{40}$ Grant R. Jeffrey, Finding Financial Freedom: A Biblical Guide to Your Independence, (Colorado Springs:

Random House, 2005), 44. James Robinson in his book "True Prosperity" applies the storehouse function to modern local church in a more subtle way. See James Robinson, True Prosperity (Carroll Stream; IL: Tyndale House Publishers, 2004), 104-108; R. T. Kendall, Tithing: A Call to Serious Biblical Giving (Grand Rapids: Zondervan, 1983), 75-79.

${ }^{41}$ Jim Good, Selected to Suffer (Mustang: OK: Tate Publishing, 2010), 75; Ken Hemphill, Making a Change: Transformational Guide to Christian Money Management (Nashville Broadman and Hollman Publishing, 2006), 112; Malone, 28-29.

${ }^{42}$ Randy C. Alcorn, Money, Possessions and Eternity, (Wheaton: Tyndale House Publishers, 1989), 174-175; Kendall, 79.

43 John Walvoord and Roy Zuck caution their readers, clarifying that God did not give Christians promises for obedience, this was a feature of the unique covenant that Israel possessed. See Walvoord and Zuck, 1585.
} 
tithing (3:8-12) is addressed to a corporate body, using plural pronouns, a nuance easily missed in most modern English translations. Tithes were designed to support the temple system and the priests (Lev. 27:31-34, Num. 18:26, Deut. 12:6; 26:12). The temple storehouse (beit haotzer) insured that the priests would have food provided for them. The offer to test God with tithes is made in the context of the covenant as was outlined in Deut. 14:29. ${ }^{44}$ Thus, the well-being of the nation depends on the corporate obedience of the nation to this commandment and that kind of prosperity promise may not appear so attractive. When one's blessing and prosperity is dependent on the obedience of everyone else, it takes the wind of optimism out of one's sail. The promises of abundant blessings in Malachi do not appear to be individualistic or personal, but were made to a nation and the blessing of one person in the community is dependent on the obedience of the majority. Such were the mechanics of a national covenant and the time in which Malachi calls Israelites to return to the practice of tithing in a time of national restoration.

\section{Conclusion}

Having looked briefly at two examples of Malachi's oracles and their diverse readings and applications allows one to see the importance of seeking the interpretation that would reflect the oracles' immediate context. Certainly not all questions can be answered through the careful examination of the historical and cultural background. Nevertheless, from internal references, it appears that Malachi's oracles were not messages about individual conduct, but rather a strong critique of widespread corporate social behaviors of his generation. Though so little is known of the prophet who brought forth these utterances, the historical events, the social and religious climate of his day provide valuable background for interpreting the intent of his words as well as disclose the desired goals of his message. From history and the comparison of other prophetic

\footnotetext{
44 John Goldingay and Pamela Scalise, New International Biblical Commentary: Minor Prophets II (Peabody: Hendrickson Publishers, 2009), 355.
} 
texts it seems that Malachi builds on the expectations set forth by preceding prophets and seeks to revive the proper motivation and spiritual fervor among the subsequent generations of the returned exiles. The oracles are certainly colored by the complexities of his setting and should be read as calls to invigorate communal faithfulness towards God who remains in covenant with his people. The cultural and historical background of national restoration and covenant fidelity in Malachi is undergirded by calls for corporate unity.

Recognizing the corporate subtext of Malachi's messages and the nationalistic protectionism stemming from an unstable political and social atmosphere offers a context-driven interpretive lens. No doubt that today Malachi's utterances will continue to make a significant impact on religious worldviews, theology and praxis. The implications of interpretations stemming from two pronouncements addressed in this paper should be sufficient to illustrate the value of reading the prophet in his original context. Undoubtedly, with some skill Malachi's pronouncements can be successfully contextualized to modern audiences, but the concerns of his day cannot be omitted or ignored in the process of applying them other contexts. 


\section{Bibliography}

Alcorn, Randy C. Money, Possessions and Eternity. Wheaton: Tyndale House Publishers, 1989.

Alden, Robert L., “Malachi.” In The Expositor's Bible Commentary: Daniel-Malachi, Vol. 7, gen. ed. Frank E. Gaebelein. Grand Rapids: Zondervan, 1984.

Baldwin, Joyce G. Haggai, Zechariah, Malachi: An Introduction and Commentary. Downers Grove: Inver-Varsity Press, 1972.

Bock, Darryl L. Luke. Downers Grove: Inter-Varsity Press, 1994.

Booth, Annice. Secrets of Prosperity: Abundance in the $21^{\text {st }}$ Century. Gardiner: MT: Summit University Press, 2000.

Brin, Gershon. "Divorce and Qumran.” In Legal Text and Legal Issues, edited by M. Bernstein, F. Garcia Martinez, J. Kempen. Leiden: Netherlands: Brill Publishing, 1997.

Bruggemann, Walter. An Introduction to the Old Testament: The Canon and Christian Tradition. Louisville: Westminster John Knox, 2003.

Buttrick, George Arthur, gen. ed. The Interpreter's Bible, Vol. VI. New York: Abingdon, 1956

Campbell, Ken M. Marriage and Family in the Biblical World. Downers Grove: Inver-Varsity Press, 2003.

Chatty, Danzil, Divorce Discourses: A Biblical Dilemma, New Delhi: India: Concept Publishing, 2007.

Childs, Brevard S. Introduction to the Old Testament as Scripture. Philadelphia: Fortress Press, 1982.

Cogan, Mordechai “Achaemenid Inscriptions: Cyrus Cylinder" in Context of Scripture, William W. Hallo and K. Lawson Younger, Leiden; Boston: Brill, 2000.

Collins, John J. "Marriage, Divorce and Family in Second Temple Judaism.” In Families in Ancient Israel. Louisville: Westminster John Knox Press, 1997.

Craigie, Peter C. Twelve Prophets, Vol. II. Louisville: Westminster John Knox Press, 1885.

Dillard, Raymond B., Tremper Longman III. An Introduction to the Old Testament. Grand Rapids: Zonvervan, 1994.

Driver, S. R. An Introduction to the Old Testament Literature. Cleveland: The Word Publishing, 1963. 
Dunn, James D.G. and Scot McKnight, eds., [Book Title Needed] Winona Lake: Eisenbrauns, 2005.

Eissfeldt, Otto, Peter R. Ackroyd, trans. The Old Testament: An Introduction. New York: Harper and Row Publishers, 1965.

Feinberg, Charles L. The Minor Prophets. Chicago: Moody Press, 1976.

Geisler, Norman L. A Popular Survey of the Old Testament. Grand Rapids: Baker Book House, 1987.

Goldingay, John. Old Testament Theology: Israel's Life. Downers Grove: Inter-Varsity Press, 2009.

Goldingay, John and Pamela Scalise. New International Biblical Commentary: Minor Prophets II. Peabody: Hendrickson Publishers, 2009.

Good, Jim. Selected to Suffer. Mustang: OK: Tate Publishing, 2010.

Hale, Tom and Stephen Thorson. Applied New Testament Commentary: Applying God's Word to Your Life. Colorado Springs: David C. Cook Publications, 2007.

Hemphill, Ken. Making a Change: Transformational Guide to Christian Money Management. Nashville Broadman and Hollman Publishing, 2006.

Hill, Andrew E. The Anchor Bible: A New Translation with Commentary: Malachi. New York: Doubleday Dell Publishing, 1998.

Hughes, Kent, R. The Sermon on the Mount: The Message of the Kingdom. Wheaton: Crossway Books, 2001.

Jeffrey, Grant R. Finding Financial Freedom: A Biblical Guide to Your Independence. Colorado Springs: Random House, 2005.

Jill-Levine, Amy. "The Word Becomes Flesh: Jesus, Gender and Sexuality." In Historical Jesus in Recent Research Vol. 10. Location: Publisher, Date.

Kaiser, Walter C., Malachi: God's Unchanging Love, Grand Rapids: Baker Book House, 1984. Messiah in the Old Testament. Grand Rapids: Zondervan, 1995.

Kaiser, Walter C., Peter H. Davis, F.F. Bruce, Manfred T. Brauch eds. Hard Sayings of the Bible. Downers Grove: Inver-Varsity Press, 1996.

Kendall, R. T. Tithing: A Call to Serious Biblical Giving. Grand Rapids: Zondervan, 1983. 
Malone, Meade W. The Plan: Unlocking God's Financial Blessing for Your Life. Bloomington: Author House, 2010.

Manson, Thomas Walter. The Teaching of Jesus: Studies of its Form and Content. New York: Cambridge University Press, 1955.

Marsman, Hennie J. Women in Ugarit and Israel: Their Social and Religious Position in the Context of Ancient Near East. Leiden: Netherlands: Brill Publishing, 2003.

Merrill, Eugene H. An Exegetical Commentary: Haggai, Zechariah, Malachi. Chicago: Moody Press, 1994.

Peterson, David L. Zechariah 9-14 and Malachi: A Commentary. Louisville: Westminster John Knox Press, 1995.

Post, Steven, G. "Family." In Encyclopedia of Christianity, edited by Erwin Fahlbusch, translated by Geoffrey William Bromiley. Grand Rapids: Eerdmans, 2001.

Robinson, James. True Prosperity. Carroll Stream; IL: Tyndale House Publishers, 2004.

Smith, John Merlin Powis. ICC: The Exegetical Critical Commentary on the Book of Malachi. Skokie, IL: Vrada Books, 2005.

Tarazi, Paul Nadim. The Old Testament: An Introduction, Vol. 2. Crestwood, NY: St. Vladimir's Seminary Press, 1994.

Verhoef, Pieter A. The Books of Haggai and Malachi. Grand Rapids: Eerdmans, 1986.

Yong-Gi Cho, David. Solving Life's Problems. Alachua: FL: Logos Bridge Foundation, 1980.

Walvoord John F., Roy B. Zuck. The Bible Knowledge Commentary. Colorado Springs: Cook Communications, 2000.

Wade, Peter. Seeds and Secrets: Cultivating God's Seeds and Applying His Secrets to Become Victors, Not Victims. Seaford, AU: Positive Word Ministries, 2008.

Weyde, Karl William. Prophecy and Teaching. New York: De Gruyter, 2000. 